\title{
PENGARUH PENGGUNAAN METODE DEMONSTRASI TERHADAP KEMAMPUAN BERBAHASA EKSPRESIF ANAK USIA DINI DI TK AISYIYAH CABANG PINRANG BARAT KABUPATEN PINRANG
}

\author{
*Agustina \\ TK Aisyiyah Bustanul Athfal Tanapute, Wajo, Indonesia \\ *Email Korespondensi: agustinajabir12@gmail.com
}

\section{INFO ARTIKEL}

Diterima 11 Desember 2021 Direvisi 13 Desember 2021 Dipublikasikan 31 Desember 2021

\begin{abstract}
A B STR A K
Penelitian ini dilaksanakan karena ditemukan gejala rendahnya kemampuan berbahasa ekspresif anak Taman kanak-kanak Aisyiyah Cabang Pinrang Barat Kabupaten Pinrang. Penelitian ini bertujuan untuk mengetahui gambaran penggunaan metode demonstrasi, gambaran kemampuan berbahasa ekspresif dan pengaruh penggunaan metode demonstrasi terhadap kemampuan berbahasa ekspresif pada Taman Kanak-Kanak Aisyiyah Cabang Pinrang Barat. Populasi penelitian ini adalah anak didik Taman Kanak-Kanak Aisyiyah Cabang Pinranga Barat yang berjumlah 50 anak. Selanjutnya dipilih yang berusia 5-6 tahun sehingga diperoleh 20 orang sampel, dengan menggunakan teknik sampling purposive sampling. Pengumpulan data dilakukan dengan test dan observasi. Data yang diperoleh dianalisis dengan menggunakan statistik deskriptif dan inferensial. Statistik inferensi yang digunakan adalah uji wilcoxon. Hasil Penelitian menunjukkan bahwa Penggunaan metode demonstrasi pada Taman Kanak-Kanak Aisyiyah Cabang Pinrang Barat adalah baik, karena setelah metode demonstrasi ini diterapakan, terjadi peningkatan kemampuan yang signifikan anak-anak pada Taman KanakKanak Aisyiyah Cabang Pinrang Barat, kemampuan berbahasa ekspresif di Taman Kanak-Kanak Aisyiyah Cabang Pinrang Barat sebelum metode demonstrasi diterapkan diperoleh dari sepuluh butir pernyataan kemampuan yang diujikan ratarata mereka dapat berbahasa 11 item dan setelah metode demonstrasi diterapkan kemampuan mereka dapat meningkat dimana mereka rata-rata dapat mengekspresikan bahasanya, ada pengaruh penggunaan metode demonstrasi terhadap kemampuan berbahasa ekspresif pada anak Taman Kanak-Kanak Aisyiyah Cabang Pinrang Barat.
\end{abstract}

Kata Kunci: Metode Demonstrasi, Kemampuan Berbahasa Ekspresi

\section{THE EFFECT OF USING THE DEMONSTRATION METHOD ON EXPRESSIVE LANGUAGE CAPABILITIES OF EARLY CHILDREN IN AISYIYAH TK BRANCH BARAT PINRANG, PINRANG REGENCY}

\begin{abstract}
This research was carried out because it was found that there were symptoms of low expressive language skills of children at Aisyiyah Kindergarten, Pinrang Barat Branch, Pinrang Regency. This study aims to determine the description of the use of the demonstration method, the description of expressive language skills and the effect of using the demonstration method on expressive language skills at Aisyiyah Kindergarten, West Pinrang Branch.
\end{abstract}


The population of this research is the 50 children of Aisyiyah Kindergarten, Pinranga Barat Branch. Then, those aged 5 6 years were selected so that 20 samples were obtained, using purposive sampling technique. Data collection is done by test and observation. The data obtained were analyzed using descriptive and inferential statistics. The inference statistic used is the Wilcoxon test. The results showed that the use of the demonstration method at Aisyiyah Kindergarten, Pinrang Barat Branch was good, because after this demonstration method was applied, there was a significant increase in the ability of children at Aisyiyah Kindergarten, Pinrang Barat Branch, expressive language skills in Kindergarten. -Kanak Aisyiyah, West Pinrang Branch, before the demonstration method was applied, it was obtained from ten items of ability statements that were tested on average they could speak 11 items and after the demonstration method was applied their abilities could increase where on average they could express their language, there was an effect of using the demonstration method on expressive language skills in the children of Aisyiyah Kindergarten, West Pinrang Branch.

Keyword: The Demonstration Method, Expressive Language Ability

\section{Pendahuluan}

Guru memiliki peran yang sangat besar dalam menentukan hasil belajar yang akan dicapai. Seorang guru diharapkan dapat memilih metode pengajaran yang tepat sehingga apa yang diharapkan dapat terealisasi. Guru sebagai kunci utama dalam pembelajaran, harus memiliki strategi belajar yang tepat dan akurat (Nuraeni, 2013).

Salah satu cara yang dapat digunakan agar tujuan pembelajaran sesuai dengan yang diharapkan adalah dengan menggunakan metode pembelajaran yang tepat (Mansyur Hamdani, 2021). Metode adalah suatu cara yang dipilih dan digunakan untuk mencapai suatu tujuan. Metode pembelajaran adalah metode mengajar yang digunakan agar tujuan pembelajaran dapat dicapai. Ada berbagai macam metode pembelajaran, namun efektivitas atau hasilnya kadang berbeda antara satu guru dengan guru yang lain. Pemilihan metode pembelajaran terkadang menimbulkan konfrontasi, karena baik bagi seorang guru, belum tentu baik bagi guru lain. Hal ini dikarenakan berbagai faktor yang turut andil menentukan berhasil tidaknya metode tersebut dilaksanakan, misalnya kesiapan guru, karakter siswa, sarana dan prasarana atau fasilitas yang tersedia (Tanu, 2019).

Pemilihan metode pengajaran terutama di lingkungan taman kanak-kanak (TK) tentulah sangat berbeda dengan metode pengajaran di tingkat sekolah yang lebih tinggi. Pada fase di TK, pemilihan metode yang tepat haruslah bersifat menyenangkan, bermain dan seni. Prinsip belajar sambil bermain merupakan hal yang wajib diterapkan pada fase TK. Hal ini dimaksudkan, agar anak-anak bisa belajar namun tidak menghilangkan karakternya yang merupakan fase bermain. Pemilhan metode pembelajaran pada fase TK yang melibatkan belajar sambil bermain diharapkan dapat membuat anak-anak lebih mandiri dan mau belajar sehingga tujuan dapat tercapat (Herlina, 2016).

Salah satu metode yang dianggap efektif diterapkan pada tingkat TK adalah metode demonstrasi. Metode demonstrasi adalah suatu metode yang dilakukan dengan cara menunjukkan dan mempraktekkan melalui gerakan-gerakan atau cara-cara melakukan sesuatu yang disertai dengan keterangan atau penjelasan. Penggunaan metode ini akan membuat murid mengamati apa yang mereka lihat, sehingga melatih kemampuan berfikir dan daya tangkap serta daya ingat mereka (Herlina, 2016).

Pemberian penjelasan tentang apa yang dipraktekkan oleh guru tentu juga harus dibarengi dengan pemilihan kata atau ucapan yang benar dan sederhana sehingga dapat dipahami oleh murid. Komunikasi dua arah merupakan hal yang mutlak dilakukan, sehingga murid-murid yang notabene masih berumur sangat dini tersebut, akan merasa memiliki saran melalui komunikasi, sehingga murid-murid akan terlatih menggunakan bahasa yang baik (Agustiniari et al., 2014).

Bahasa bagi anak sangat penting, karena dengan memiliki kemampuan berbahasa yang baik, maka anak dapat mengkomunikasikan pikiran, perasaan dan keinginannya. Penggunaan bahasa pada anak usia prasekolah dinyatakan dalam bentuk isyarat, simbol, lisan, bilangan, lukisan maupun mimik untuk mengungkapkan sesuatu. Terdapat dua hal dalam proses terjadinya bicara, yaitu: 
1. Aspek sensoris, meliputi: pendengaran, penglihatan, dan rasa raba. Hal berfungsi untuk memahami apa yang di dengar, dilihat, dan dirasa.

2. Aspek motorik yaitu mengatur laring, alat-alat artikulasi, tindakan artikulasi dan laring yang bertanggung jawab untuk pengeluaran suara.

Kenyataan di atas menunjukkan bahwa pendidikan dan pelatihan bahasa sangat berpengaruh penting. Semakin baik kemampuan bahasa anak. maka semakin baik pula pendidikan dan pelatihan bahasa yang didapat. Konsekuensi logis dari hal tersebut adalah para guru, terutama guru taman kanak-kanak yang harus mampu menciptakan situasi belajar dan model pembelajaran yang baik bagi anak, dalam arti bagaimana metode seorang guru menciptakan situasi belajar, sehingga dapat mengembangkan kemampuan berbahasa anak, karena hal ini akan berpengaruh besar dalam perkembangan bahasa anak didik ke depan.

Bahasa merupakan salah satu parameter perkembangan anak. Kemampuan bicara dan bahasa melibatkan perkembangan kognitif, sensorimotor, psikologis, emosi dan lingkungan sekitar anak. Kemampuan bahasa pada umumnya dapat di dibedakan atas kemampuan reseptif (mendengar dan memahami) dan kemampuan ekspresif (berbicara). Bicara adalah kemampuan anak untuk berkomunikasi dengan bahasa oral yang membutuhkan kombinasi serasi dari sistem neuromuscular untuk mengeluarkan fonasi dan artikulasi suara. Proses bicara melibatkan beberapa sistem dan fungsi tubuh seperti sistem pernapasan, pusat khusus pengatur bicara di otak dalam korteks serebri, pusat respirasi didalam batang otak dan struktur artikulasi, resonasi dari mulut serta rongga hidung.

Khusus anak-anak usia taman kanak-kanak, pembelajaran bahasa harus dirancang sedemikian rupa sehingga akan memberikan konstribusi besar bagi perkembangan bahasa anak baik metode, materi maupun situasi pembelajaran. Kemampuan bahasa anak usia dini diperoleh dan dipelajari anak secara alami untuk menyesuaikan diri dengan lingkungannya, sehingga anak akan mampu bersosialisasi, berinteraksi dan merespon orang lain. Anak usia dini merupakan wahana yang sangat penting dalam mengembangkan bahasa anak, sehingga kondisi seperti ini dapat menfasilitasi pengembangan keterampilan berbahasa pada anak usia dini, anak memperoleh bahasa dari lingkungan keluarga dan lingkungan tetangga. Dengan kosakata yang mereka memiliki, maka pertumbuhan kosa kata anak akan tumbuh dengan cepat seperti yang dikemukakan oleh Sroufe (1996) pertumbuhan kosa kata anak akan lebih cepat setelah mereka mulai berbicara.

Belajar bahasa sangat krusial terjadi sebelum enam tahun. Oleh karena itu pendidikan anak usia dini merupakan wahana yang sangat penting dalam mengembangkan bahasa anak sehingga dapat memfasilitasi pengembangan keterampilan berbahasa anak usia dini. Anak memperoleh bahasa dari lingkungan keluarga dan lingkungan tetangga. Dengan kosa kata anak akan bertambah dan tumbuh dengan cepat seperti di kemukakan oleh Scoufe (1996) pertumbuhan kosa kata anak akan lebih cepat setelah mereka mulai berbicara.

Seorang guru perlu menciptakan suasana belajar yang menyenangkan bagi anak dan menggunakan berbagai metode yang tepat. Hal ini dimaksudkan untuk mempertahankan dan meningkatkan motivasi belajar anak didik. Bertitik tolak dari hal tersebut, maka dapat dipahami belajar bahasa bagi anak didik memerlukan perhatian, pemahaman dan metode yang tepat. Penelitian mengenai pengaruh penggunaan metode demonstrasi terhadap kemampuan berbahasa ekspresif anak usia dini di TK Aisyiyah cabang Pinrang Barat Kabupaten Pinrang belum pernah dilakukan, sehingga hasilnya belum pernah dilaporkan. Hal inilah yang melatarbelakangi penelitian ini dilakukan. Tujuan penelitian ini yaitu untuk mengetahui gambaran penggunaan metode demonstrasi, kemampuan bahasa ekspresif adan pengaruh penggunaan metode demonstrasi terhadap kemampuan bahasa ekspresif anak usia dini di Tk Aisyiyah Cabang Pinrang Barat.

\section{Metode Penelitian}

\subsection{Jenis Penelitian}

Jenis penelitian ini yaitu ekperimen Pre Eksperimental Design (eksprimen yang belum baik). Stanley (dalam Arikunto, 1997:11) menjelaskan bahwa penelitian ekspimen berdasarkan baik dan buruknya 
eksperimen atau sempurna tidaknya eksprimen terdiri dari dua kelompok, yaitu Pre Eksperimental Design (eksprimen yang belum baik) dan True Eksprimen Design (Eksprimen yang sudah dianggap baik).

\subsection{Desain Penelitian}

Desain penelitian yang digunakan oleh peneliti ialah Pretes and Posstest One Group Disign. Pada desain ini sampel diberi Pretest terlebih dahulu untuk mengetahui kemampuan awal sebelum diberi perlakuan, kemudian diberi perlakuan, dengan demikian hasil perlakuan dapat diketahui lebih akurat, karena dapat dibandingkan dengan keadaan sebelum dan sesudah diberi perlakuan (Sugiyono, 2010:111)

\subsection{Variabel Penelitian}

Variabel penelitian ada dua, yaitu variable bebas $(\mathrm{X})$ dan variable terikat $(\mathrm{Y})$. Variabel bebas pada penelitian ini adalah penggunaan metode demonstrasi dan variabel terikatnya yaitu kemampuan berbahasa ekspresif.

\subsection{Populasi dan Sampel}

Populasi yang digunakan dalam penelitian ini adalah seluruh peserta didik Tk Aisyiyah cabang Pinrang Barat tahun pelajaran 2012 / 2013 kelompok B sebanyak 50 anak. Tekhnik sampling yang digunakan adalah non probability sampling dengan cara purposive sampling dimana pengambilan sampel dilakukan dengan tehnik mengambil anggota sampel sebanyak 20 anak dengan pertimbangan untuk efektifitas pembelajaran dalam satu kelas dengan rasio jumlah anak sebanyak yang disebutkan diatas.

\subsection{Tekhnik Pengumpulan dan Analisa Data}

Tekhnik pengumpulan data pada penelitian ini menggunakan instrument berupa observasi dan tes. Pada penelitian ini dilakukan observasi partisipan, dimana peneliti terlibat dengan kegiatan sehari-hari dengan sumber data penelitian, sehingga data yang diperoleh lebih lengkap, tajam dan sampai mengetahui pada tingkat makna dari setiap perilaku yang nampak. Tes dilakukan untuk mengetahui hasil kemampuan bahasa anak, peneliti menggunakan pengukuran yang ditetapkan validator satu ahli bahasa dan validator dua oleh psikolog dengan menggunakan skoring skala 0-5. Setelah mendapatkan data yang cukup, selanjutnya data dianalisis menggunakan statistik deskriptif dan inferensial.

\section{Hasil Penelitian}

Gambaran penerapan penggunaan metode demonstrasi dalam pembelajaran anak usia dini di Tk Aisyiyah Cabang Pinrang Barat terbagi dalam empat tahap yakni: (a). Tahap persiapan, (b). Tahap awal, (c). Tahap inti, (d). Tahap penutup. Pelaksanaan dilakukan sebanyak 10 kali pertemuan. Penggunaan metode demostrasi bertujuan untuk meningkatkan kemampuan anak yang melibatkan secara langsung dalam kegiatan pembelajaran

Gambaran Kemampuan Bahasa Ekspresif Anak Usia Dini Tk Aisyiyah Cabang Pinrang Barat meliputih empat aspek, yaitu (1) bercerita; (2) mengungkapkan bahasa; (3) menyusun gambar; (4) bermain. Keempat indikator tersebut selanjutnya dikembangangkan menjadi 10 butir pertanyaan, setiap butir pertanyaan memiliki nilai minimal 0 dan maksimal 5 seperti terluhat pada tabel 1 berikut.

Tabel I. Deskripsi Kemampuan Bahasa Ekspresif (bercerita)

\begin{tabular}{|c|c|c|c|c|c|}
\hline \multirow[b]{2}{*}{ Interval Nilai } & \multirow[b]{2}{*}{ Kategori } & \multicolumn{2}{|c|}{ Pretest } & \multicolumn{2}{|c|}{ Posttest } \\
\hline & & Frekuensi & $\begin{array}{c}\text { Persentas } \\
\text { e }\end{array}$ & Frekuensi & Persentase \\
\hline $0-17$ & Rendah & 16 & 80.0 & 0 & 0 \\
\hline $18-33$ & Sedang & 4 & 20,0 & 8 & 40.0 \\
\hline $34-50$ & Tinggi & 0 & 0 & 12 & 60.0 \\
\hline Jumlah & & 20 & $100 \%$ & 20 & $100 \%$ \\
\hline
\end{tabular}


Pretest adalah pemberian tugas sebelum dilakukan metode deminstrasi, sedangkan post test artinya pemberian tugas setelah dilakukan metode demonstrasi. Pre test berfungsi untuk mengukur kemampuan awalpara responden yang digunakan, dalam hal ini siswa-siswa TK Aisyiyah Cabang Pinrang Barat Kabupaten Pinrang.

Tabel 1 tersebut menegaskan bahwa, sebagian besar data kemampuan bahasa ekspresif sebelum penelitian (pretest) berada pada kategori rendah, sedangkan setelah dilakukan perlakuan (posttest) dengan menggunakan metode demonstrasi, maka terjadi peningkatan. Hal ini menunjukkan bahwa kemampuan bahasa ekspresif anak mengalami peningkatan setelah dilakukan perlakuan dengan menggunakan metode demonstrasi, yang berarti bahwa metode demonstrasi efektif untuk meningkatkan ekspresif dan kemampuan berbahasa objek penelitian.

Tabel II. Deskripsi Kemampuan bermain kotak raba (mengungkapkan bahasa)

\begin{tabular}{|c|c|c|c|c|c|}
\hline \multirow{2}{*}{ Interval Nilai } & \multirow[b]{2}{*}{ Kategori } & \multicolumn{2}{|c|}{ Pretest } & \multicolumn{2}{|c|}{ Posttest } \\
\hline & & Frekuensi & $\begin{array}{l}\text { Persentas } \\
\text { e }\end{array}$ & Frekuensi & Persentase \\
\hline $0-5$ & Rendah & 16 & 80.0 & 0 & 0 \\
\hline $6-10$ & Sedang & 4 & 20.0 & 11 & 55,0 \\
\hline $11-15$ & Tinggi & 0 & 0 & 9 & 45,0 \\
\hline \multirow[t]{3}{*}{ Jumlah } & & 20 & $100 \%$ & 20 & $100 \%$ \\
\hline & Mean & & 4,250 & & 11,650 \\
\hline & Std. Error of & lean & 0,298 & & 0,301 \\
\hline \multirow{4}{*}{ 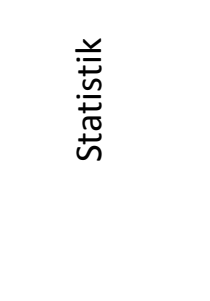 } & Median & & 4,500 & 焉 & 11,000 \\
\hline & Modus & & 5 & $\frac{\tilde{n}}{\bar{\pi}}$ & 11 \\
\hline & Std.Deviasi & & 1,332 & z & 1,348 \\
\hline & Varians & & 1,776 & & 1,818 \\
\hline
\end{tabular}

Tabel 2 tersebut menegaskan bahwa sebagaian besar data kemampuan bermain kotak raba pada awal penelitian berdasarkan nilai pretest berada pada kategori rendah $(80,00 \%)$, sedangkan pada saat setelah dilakukan perlakuan berada pada kategori sedang (55,0\%) dengan interval nilai $6-11$. Hal ini menunjukkan bahwa terjadi peningkatan sebesar 7,40 atau $49,33 \%$. Data tersebut berarti bahwa kemampuan bermain kotak raba mengalami peningkatan setelah dilakukan perlakuan dengan menggunakan metode demonstrasi dan metode ini bersifat efektif dalam merangsang otak para peserta didik untuk lebih kreatif.

Tabel 3 mempelihatkan tentang kemampuan bercerita dengan gambar. Hasil penelitian menunjukkan bahwa, sebelum dilakukan treatment yaitu pada fase pre tes, terlihat $90 \%$ anak yang tidak mampu bercerita dengan menggunakan gambar, namun setelah perlakuan menggunakan metode demonstrasi, terlihat terjadi peningkatkan. Terlihat pada tabel tersebut bahwa $30 \%$ anak yang telah dapat bercerita menggunakan gambar. Hal ini berarti bahwa penggunaan metode demonstrasi efektif untuk merangsang anak sehingga dapat berkomunikasi meskipun hanya melihat gambar. 
Tabel III. Gambaran Kemampuan bercerita dengan gambar

\begin{tabular}{|c|c|c|c|c|c|}
\hline \multirow[b]{2}{*}{ Interval Nilai } & \multirow[b]{2}{*}{ Kategori } & \multicolumn{2}{|c|}{ Pretest } & \multicolumn{2}{|c|}{ Posttest } \\
\hline & & Frekuensi & $\begin{array}{c}\text { Persentas } \\
\mathrm{e}\end{array}$ & Frekuensi & Persentase \\
\hline $0-5$ & Rendah & 18 & 90.0 & 0 & 0 \\
\hline $6-10$ & Sedang & 2 & 10.0 & 14 & 70.0 \\
\hline $11-15$ & Tinggi & 0 & 0 & 6 & 30.0 \\
\hline Jumlah & & 20 & $100 \%$ & 20 & $100 \%$ \\
\hline \multirow{6}{*}{ 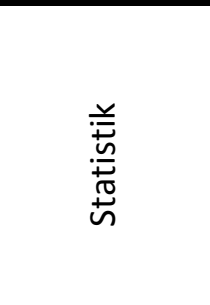 } & Mean & & 3,700 & \multirow{6}{*}{ 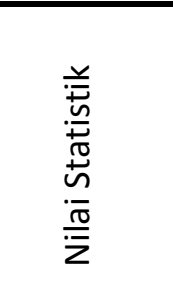 } & 11,150 \\
\hline & Std. Error o & lean & 0,241 & & 0,493 \\
\hline & Median & & 3,000 & & 10,500 \\
\hline & Modus & & 5 & & 9 \\
\hline & Std.Deviasi & & 1,080 & & 2,207 \\
\hline & Varians & & 1,168 & & 4,871 \\
\hline
\end{tabular}

Aspek kemampuan bercerita dengan gambar terdiri dari tiga item pertanyaan, dengan interval skor 0 5, kemampuan sedang dengan interval skor 6-10 dan kemampuan tinggi dengan interval skor 11-15.

a. Gambaran Kemampuan menyusun gambar

Aspek kemampuan menyusun gambar terdiri dari dua item / pertanyaan dengan kategori kemampuan yaitu kemampuan rendah dengan interval skor $0-3$, kemampuan sedang dengan interval skor $4-7$ dan kemampuan tinggi dengan interval skor $8-10$. Untuk memperoleh gambaran kemampuan menyusun gambar selengkapnya dapat dilihat pada tabel berikut ini:

Tabel IV. Deskripsi Kemampuan menyusun gambar

\begin{tabular}{|c|c|c|c|c|c|}
\hline \multirow[b]{2}{*}{ Interval Nilai } & \multirow[b]{2}{*}{ Kategori } & \multicolumn{2}{|c|}{ Pretest } & \multicolumn{2}{|c|}{ Posttest } \\
\hline & & Frekuensi & $\begin{array}{c}\text { Persentas } \\
\text { e }\end{array}$ & Frekuensi & Persentase \\
\hline $0-3$ & Rendah & 20 & 100.0 & 0 & 0 \\
\hline $4-7$ & Sedang & 0 & 0 & 15 & 75.0 \\
\hline $8-10$ & Tinggi & 0 & 0 & 5 & 25.0 \\
\hline Jumlah & & 20 & $100 \%$ & 20 & $100 \%$ \\
\hline \multirow{6}{*}{ 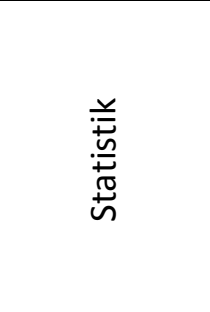 } & Mean & & 1,000 & \multirow{6}{*}{ 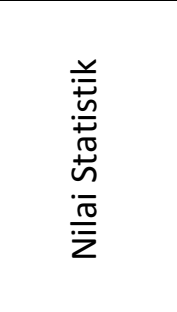 } & 6,450 \\
\hline & \multicolumn{2}{|c|}{ Std. Error of Mean } & 0,229 & & 0,223 \\
\hline & \multicolumn{2}{|l|}{ Median } & 1,000 & & 6,000 \\
\hline & \multicolumn{2}{|l|}{ Modus } & 0 & & 6 \\
\hline & \multicolumn{2}{|l|}{ Std.Deviasi } & 1,025 & & 0,998 \\
\hline & \multicolumn{2}{|l|}{ Varians } & 1,053 & & 0,997 \\
\hline
\end{tabular}

Dari tabel 4 dapat dijelaskan bahwa sebagaian besar data kemampuan menyusun gambar pada awal penelitian sebagian seluruhnya berada pada kategori rendah sebesar $100 \%$ sedangkan pada saat setelah dilakukan perlakuan dengan metode demonstrasi berada pada kategori sedang sebesar $75,0 \%$ Jika 
dibandingkan dengan nilai rata-rata pretest dan posttest yang diperoleh sebesar 1,000 dan 6,450 , terjadi peningkatan sebesar 5,45 atau $54,5 \%$.

b. Gambaran kemampuan bermain boneka tangan

Aspek kemampuan bermain boneka tangan terdiri dari dua item / pertanyaan dengan kategori kemampuan rendah dengan interval skor $0-3$, kemampuan sedang dengan interval skor $4-7$ dan kemampuan tinggi dengan interval skor $8-10$. Untuk memperoleh gambaran kemampuan bermain boneka tangan selengkapnya dapat dilihat pada tabel berikut ini:

Tabel V. Deskripsi Kemampuan bermain boneka tangan

\begin{tabular}{|c|c|c|c|c|c|}
\hline \multirow[b]{2}{*}{ Interval Nilai } & \multirow[b]{2}{*}{ Kategori } & \multicolumn{2}{|c|}{ Pretest } & \multicolumn{2}{|c|}{ Posttest } \\
\hline & & Frekuensi & $\begin{array}{c}\text { Persentas } \\
\text { e }\end{array}$ & Frekuensi & Persentase \\
\hline $0-3$ & Rendah & 20 & 100.0 & 0 & 0 \\
\hline $4-7$ & Sedang & 0 & 0 & 19 & 95.0 \\
\hline $8-10$ & Tinggi & 0 & 0 & 1 & 5.0 \\
\hline Jumlah & & 20 & $100 \%$ & 20 & $100 \%$ \\
\hline \multirow{6}{*}{ 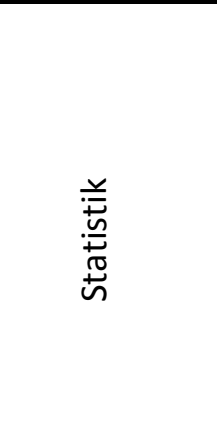 } & Mean & & 0,700 & \multirow{6}{*}{ 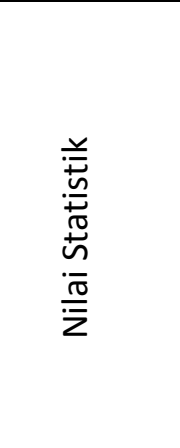 } & 5,650 \\
\hline & Std. Error o & lean & 0,127 & & 0,254 \\
\hline & Median & & 1,000 & & 6,000 \\
\hline & Modus & & 1 & & 6 \\
\hline & Std.Deviasi & & 0,571 & & 1,136 \\
\hline & Varians & & 0,326 & & 1,292 \\
\hline
\end{tabular}

Dari tabel 4.5 dapat dijelaskan bahwa sebagaian besar data kemampuan bermain boneka tangan pada awal penelitian sebagian seluruhnya berada pada kategori rendah sebesar $100 \%$, sedangkan pada saat setelah dilakukan perlakuan dengan metode demonstrasi berada pada kategori sedang sebesar 95\%, Jika dibandingkan dengan nilai rata-rata pretest dan posttest yang diperoleh sebesar 0,700 dan 5,650 , terjadi peningkatan sebesar 4,95 atau $49,5 \%$.

\section{Pembahasan}

\subsection{Penerapan Penggunaan Metode Demonstrasi}

Penerapan metode demonstrasi pada kegiatan bercerita seperti hasil pengamatan yang telah dilakukan peneliti, bahwa metode ini sangat disenangi anak-anak hingga dapat mempercepat proses pengembangan bahasa, ini terlihat pada kegiatan yang dilakukan pada awal mulai mendengarkan apa kata bu guru, menceritakan kembali cerita yang sudah disampaikan, hingga dalam beberapa menit anak juga mampu bercerita, perhatikan gambar yang berbeda diawal. Pemberian materi pada kegiatan ini menggunakan alat peraga kotak raba, boneka tangan, gambar seri dan gambar-gambar. Pada kemampuan pengembangan bahasa, anak dapat mengetahui setelah diperagakan oleh guru. Dengan kegiatan ini anak termotivasi untuk mengenal kata lebih banyak lagi hingga mereka bisa mengenal kata dan menyusunnya 
sehingga menjadi sebuah cerita sederhana.Pembelajaran bahasa permulaan dititik beratkan pada aspekaspek yang bersifat teknis seperti ketepatan menyuarakan tulisan, lafal, intonasi yang wajar, kelancaran dan kejelasan suara. (Mulyadi, 2009)

\subsection{Deskripsi Gambaran Kemampuan Bahasa Ekspresif}

Survay awal yang dilakukan peneliti menunjukkan hasil observasi akan bahasa ekspresif anak usia 5-6 tahun dari 20 anak yang dipilih menjadi sampel anak berada pada kategori rendah dan sedang. Kemampuan bercerita diawal anak kurang. Belajar bercerita diajarkan pada kelompok B semester II, anak usia 5-6 tahun anak sudah harus diajarkan bahasa. Masa peka untuk belajar membaca dan mengerti angkaangka adalah umur 4 dan 5 tahun seperti yang dikemukakan oleh Domen dan Delacato bahwa waktu yang baik untuk mengajarkan membaca kira-kira bersamaan dengan waktu anak-anak mulai belajar bicara.

\subsection{Deskripsi Pengaruh Penggunaan Metode Demonstrasi pada Kemampuan Bahasa Ekspresif Anak}

Berdasarkan temuan peneliti, terbukti dengan skor rata-rata kemampuan bahasa anak menunjukkan terjadinya peningkatan seperti yang telah diurai pada tabel diatas, hal ini disebabkan oleh pengaruh dari metode demonstrasi yang diberikan kepada anak melalui alat peraga gambar-gambar,boneka tangan lembaran kerja dan cerita bergambar, ini diberikan secara bertahap dan bergantian. Hasil yang diperoleh dari pengujian hipotesis menunjukkan bahwa ada pengaruh dari penggunaan metode demonstrasi dalam peningkatan kemampuan bahasa ekspresif anak. Hal ini ditunjukkan dengan adanya peningkatan skor bahasa ekspresif yang signifikan pada kelompok perlakuan antara sebelum dan sesudah diberi perlakuan berupa metode demonstrasi. Analisis data menggunakan teknik statistik non parametrik wilcoxon Signed Ranks Test.

Hasil penelitian ini sesuai dengan hasil penelitian (Herlina, 2016) pada anak usia 5 - 6 Tahun di TK ABA 010 Cabang Kuok Kabupaten Kampar menggunakan metodedemonstrasi , yang menyebutkan bahwa terjadi peningkatan kemampuan kemandirian anak. Selain itu, penelitian dari (Nurdini et al., 2018) pada anak kelas B di RA Al-Furqon Ciranjang Cianjur tahun pelajaran 2017-2018 menunjukkan bahwa terjadi perkembangan hasil pembelajaran praktik salat siswa dengan menggunakan metode demonstrasi. Hasil penelitian (Agustiniari et al., 2014) pada TK Kecubung juga menunjukkan bahwa terjadi peningkatan perkembangan kemampuan berbahasa pada anak saat menggunakan metode demonstrasi.

\section{Kesimpulan}

Berdasarkan hasil penelitian, maka dapat disimpulkan bahwa penerapan penggunaan metode demonstrasi melalui permainan kotak raba, menyusun gambar, bercerita dengan menggunakan boneka tanagan adalah suatu cara pengungkapan bahasa ekspresif anak secara spontan. Kemampuan pengembangan bahasa ekspresif setelah menggunakan metode demonstrasi berada pada kategori tinggi. Terdapat pengaruh penggunaan metode demonstrasi terhadap peningkatan kemampuan bahasa ekspresif anak di Tk Aisyiyah Cabang Pinrang Barat.

\section{Referensi}

Agustiniari, L. P., Suarni, N. K., \& Ujianti, P. R. (2014). Penerapan Metode Demonstrasi Untuk Meningkatkan Kemampuan Berbahasa Anak. Jurnal PG PAUD, 2(9), 1689-1699.

Herlina. (2016). Meningkatkan Kemandirian melalui Metode Demonstrasi pada Anak Usia 5-6 Tahun di Tk Aba 010 Cabang Kuok Kabupaten Kampar. Educhild: Jurnal Pendidikan Sosial Dan Budaya, 5(1), 37-45. https://www.neliti.com/publications/165286/meningkatkan-kemandirian-melalui-metodedemonstrasi-pada-anak-usia-5-6-tahun-di

Mansyur Hamdani, I. (2021). PENINGKATAN HASIL BELAJAR SISWA MENGGUNAKAN MODEL PEMBELAJARAN KOOPERATIF TIPE NUMBERED HEAD TOGETHER. Guru Membangun, 40(1), 1-11. https://jurnal.untan.ac.id/index.php/jgmm/article/view/47920 
Nuraeni. (2013). Jurnal Pengkajian Ilmu dan Pembelajaran Matematika dan IPA. Prisma Sains, 1(2), 4.

Nurdini, H. S., Mangkuwibawa, H., \& Syamiah, S. (2018). Kemampuan Salat Anak Usia Dini Melalui Metode Demonstrasi. (JAPRA) Jurnal Pendidikan Raudhatul Athfal (JAPRA), 1(1), 98-105. https://doi.org/10.15575/japra.v1i1.3388

Tanu, I. K. (2019). Penggunaan Metode Mengajar Di Paud Dalam Rangka Menumbuhkan Minat Belajar Anak. Pratama Widya : Jurnal Pendidikan Anak Usia Dini, 3(2), 14-19. https://doi.org/10.25078/pw.v3i2.733 